\title{
Hollow Mesoporous Silica Sphere (HMSS) as a Recyclable Nano-catalyst in an Efficient One-Pot Multicomponent Synthesis of 2-Amino-3-Cyano-4H-Pyran Derivatives
}

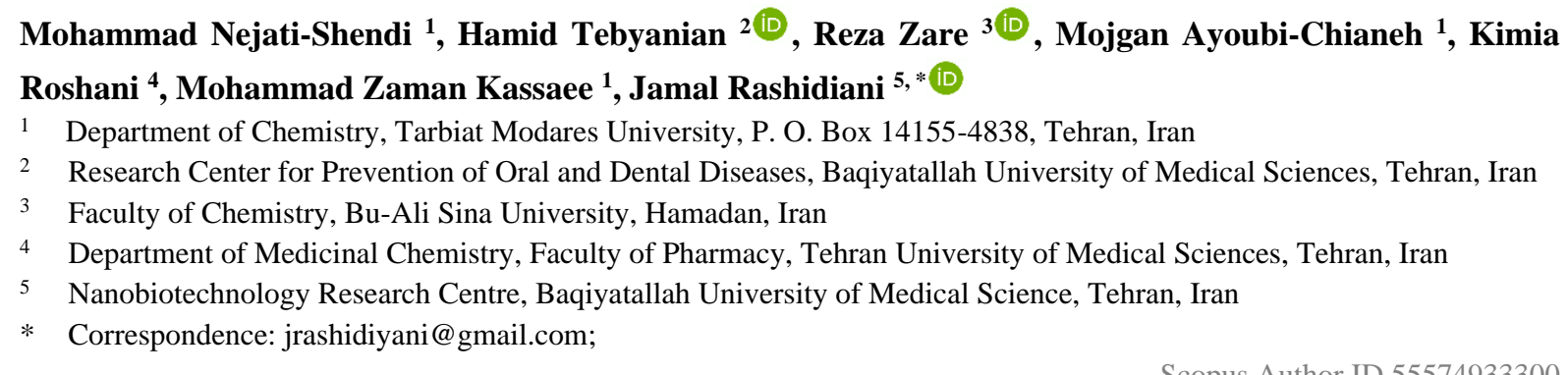

Received: 23.04.2020; Revised: 23.05.2020; Accepted: 25.05.2020; Published: 27.05.2020

Abstract: Mesoporous material has a significant role in medicine, health care, environmental monitoring, sensing the hazardous agents, and fighting against viruses and bacteria. Nano-silica sphere is an important member of the mesoporous family that noticeably flourished in biology, health care, and other industrial applications. Efficient one-pot multicomponent syntheses of 2-amino-3-cyano-4Hpyran derivatives were carried out over readily available and simply synthesized recyclable Hollow Mesoporous Silica Sphere (HMSS). Comparable yields were encountered with better efficiency, lower cost, and shorter reaction time. Hence, superior catalytic activity, flexibility, ease of recovery, tuneable hole size, and high surface to volume ratio were the major characteristics of the catalyst which distinguish this protocol from previously reported ones. The catalyst was characterized by X-ray diffraction (XRD), scanning electron microscopy (SEM), transmission electron microscopy (TEM), Fourier transform infrared (FT-IR) techniques, and nitrogen absorption and desorption (BET) analyses. The results showed that the synthesizing of HMSS catalysts under a mild and green condition in which comparable yields were encountered with better efficiency, lower cost, and shorter reaction with other major economic advantages.

Keywords: Hollow Mesoporous Silica Spheres; HMSS; Nano-catalyst; Hydrogen bond catalysis; 2amino-3-cyano-4H-pyran.

(C) 2020 by the authors. This article is an open-access article distributed under the terms and conditions of the Creative Commons Attribution (CC BY) license (https://creativecommons.org/licenses/by/4.0/).

\section{Introduction}

Hollow mesoporous silica sphere (HMSS) is considered as a great development in nanotechnology [1-5]. HMSS plays an important role in catalysis, drug delivery, imaging, biosensors, energy storage, medical and biological applications due to their controlled morphology, tuneable particle size, well-defined porous shells, specified capacity, low density, high thermal stability and biocompatibility, low toxicity, large surface to volume ratio and easy to be functionalized by chemicals [6-10]. The invention of new methods to design more convenient HMSS is noticeably attracted an excellent deal of interest, especially as a catalyst basis. Therefore various optimized structures of HMSS are investigated so far [11-17]. The most representative method to prepare HMSS is called the templating method $[18,19]$. Other various methods are also investigated [20-23]. 
Templating method applies diverse substrates as a mold followed by a shell coated onto the surface of the templates, and then removing the templates generates the hollow spheres [2428]. Recently, mesoporous silica nanoparticles (MSNs) have noticeably flourished as a sustainable catalyst in many synthetic pathways and various catalytic reactions such as Mannich-type [29-31]. To further headway in the catalytic activity of MSNs type catalysts, HMSS is developed and employed in diverse catalytic reactions [32-35]. The sol-gel method is exerted to the synthesis of non-functionalized HMSS. This process is devoid of harsh and toxic reaction conditions and benefits from excellent yield. HMSS utilizes hydrogen bonding during the catalytic cycle as a fundamental catalytic role [36-39]. 2-amino-3-cyano-4H-pyran derivatives due to a variety of potential applications are a landmark in the history of organic synthesis and play a certain role in our life scaffold. Their applications such as photonics and optoelectronic, feedstock in the production of dyes, precursors to pesticides, and chelating agents [33, 40, 41]. Such far, some works are devoted to the synthesis of 2-amino-3-cyano-4Hpyran derivatives [42-45]. Herein, the synthesis of 2-amino-3-cyano-4H-pyran derivatives is probed by considering the atom, pot, and step economy. The outstanding property of the experiment is the increment of catalyst durability, moderating the reaction cost, and reducing process time under green conditions [42, 46, 47]. The optimized reaction condition was achieved for the synthesis of 2-amino-3-cyano-4H-pyran derivatives catalyzed by HMSS (Scheme 1). In the current study, we aimed to propose a mineral-based Nano-catalyst synthesizing approach to manage and applying an organic chemical reaction to optimize pyran derivatives synthesis.

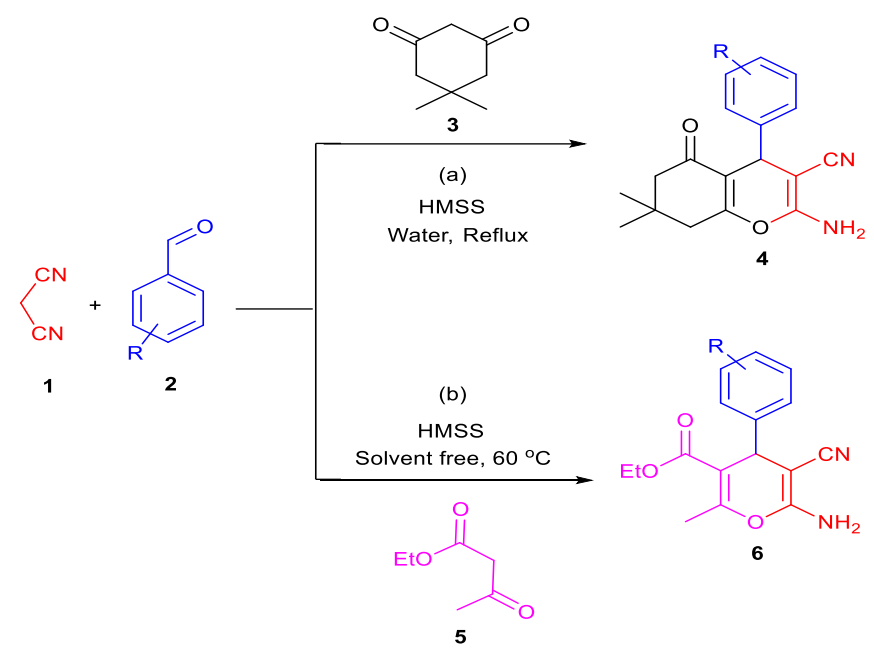

Scheme 1. Synthesis of 2-amino-3-cyano-4H-pyran derivatives catalyzed by HMSS.

\section{Materials and Methods}

\subsection{Materials.}

All chemical reagents are purchased from commercial suppliers (Aldrich and Merck Co.) used in high purity without further purification.

\subsection{Preparation of HMSS.}

The HMSS is prepared through the sol-gel method [48-50]. In the first step of HMSS synthesis, $3 \mathrm{ml}$ of tetraethyl orthosilicate (TEOS) is added to a mixture of $37 \mathrm{ml}$ ethanol, $5 \mathrm{ml}$ deionized water, and $1.6 \mathrm{ml}$ aqueous ammonia solution (25\%). The resultant mixture is stirred for $0.5 \mathrm{~h}$ at room temperature to give a white colloidal suspension. To separation silica particles, 
the suspension is centrifuged then washed with deionized water and ethanol two times. The particles are dried under a vacuum. Then $200 \mathrm{mg}$ of obtained solid silica particles $\left(\mathrm{sSiO}_{2}\right)$ are dispersed in $40 \mathrm{~mL}$ deionized water and ultra-sonicated for $20 \mathrm{~min}$. The suspension is added to a solution of $300 \mathrm{mg}$ cetyltrimethylammonium bromide (CTAB), $60 \mathrm{ml}$ ethanol, $60 \mathrm{ml}$ deionized water, and $1.1 \mathrm{ml}$ ammonia solution (25\%). After stirring the mixture at room temperature for $0.5 \mathrm{~h}, 0.5 \mathrm{~mL}$ of TEOS is quickly added and stirred for $6 \mathrm{~h}$ and centrifuged to yield $\mathrm{sSiO}_{2} @ \mathrm{CTAB} / \mathrm{SiO}_{2}$. These processes followed by redispersion of $\mathrm{sSiO} 2 @ \mathrm{CTAB} / \mathrm{SiO} 2$ in $40 \mathrm{~mL}$ of deionized water and dried under vacuum. For etching reaction, $850 \mathrm{mg}$ of $\mathrm{Na} 2 \mathrm{CO} 3$ is added to the sonicated $\mathrm{sSiO}_{2} @ \mathrm{CTAB} / \mathrm{SiO}_{2}$ while stirring the aqueous suspension. This process continues for $12 \mathrm{~h}$ under stirring vigorously at $50{ }^{\circ} \mathrm{C}$. Then the product is washed with deionized water and ethanol several times and finally dried under vacuum oven. In the final step, the CTAB surfactant is removed by heating the nanoparticles in $200 \mathrm{~mL}$ of methanol and $2.0 \mathrm{~mL}$ of concentrated $\mathrm{HCl}$ solution under stirring with a magnetic stirrer for $2 \mathrm{~h}$. The HMSS material is collected and washed with methanol then dried in vacuum [13, 29, 33, 42].

\subsection{General procedure for the synthesis of 2-amino-3-cyano-4H-pyrans.}

$10 \mathrm{mg}$ HMSS catalyst is added to the mixture of malononitrile (1) (1 mmol), benzaldehyde (2) $(1 \mathrm{mmol})$, and dimedone (3) $(1 \mathrm{mmol})$, and refluxed in the water at $80{ }^{\circ} \mathrm{C}$ to give Twelve of 2-amino-3-cyano-4H-pyrans derivatives (4). The same procedure is conducted to synthesize the other derivatives, except using $1 \mathrm{mmol}$ of ethyl acetoacetate (5) instead of 3 to yield other eight 2-amino-3-cyano-4H-pyrans derivatives (6) (Scheme 1).

\subsection{Spectral data.}

The structure and purity of the products are confirmed by spectroscopy or comparing their melting points with the authentic samples reported in the literature.

\section{Results and Discussion}

The catalyst (HMSS) is prepared and identified by XRD, SEM, FT-IR, and BET analyses (Scheme 2, Figures 1-5).

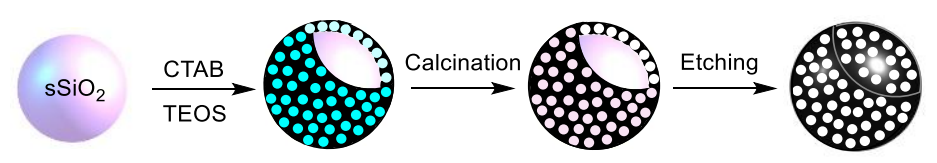

Scheme 2. Preparation of HMSS.

\subsection{XRD.}

The XRD pattern appears compatible with the HMSS structure (Figure 1). XRD pattern of HMSS shows the silica structure with two main peaks, one sharp small-angle XRD peak in the $2 \theta=2.0-2.3$ and a weak peak in the $2 \theta=3.8-4.6$ (Figure 1) [51].

\subsection{SEM.}

The topography of the catalyst surface is displayed by the SEM image (Figure 2). HMSS particles appeared with uniform spherical morphology. Particle sizes are estimated between 190-220 nm. SEM images are taken on a Mira3 Tescan instrument. 


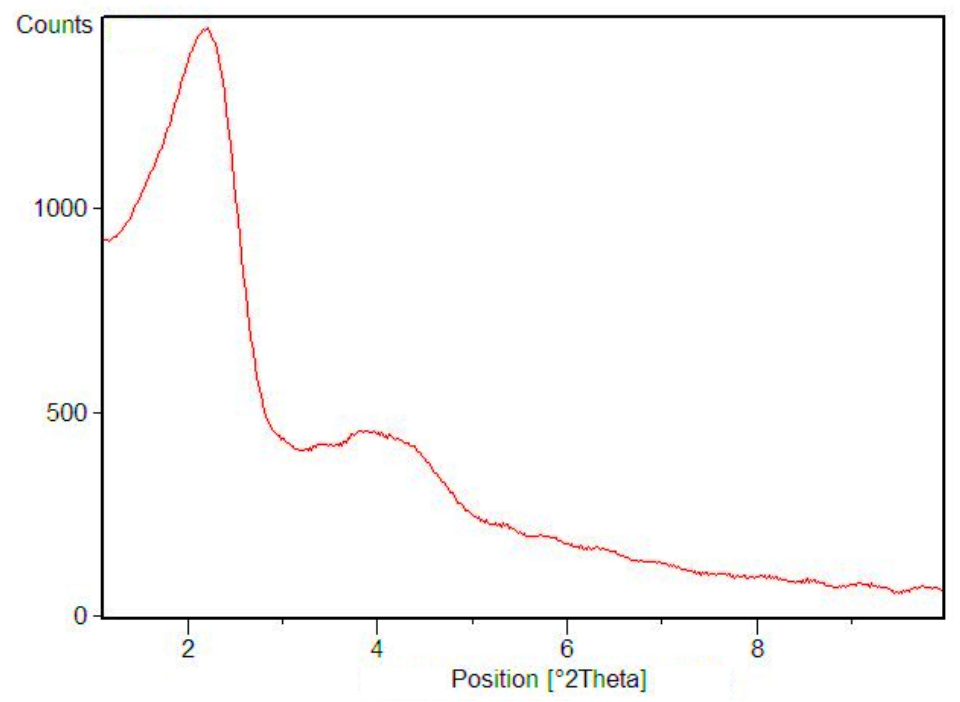

Figure 1. XRD pattern of HMSS.

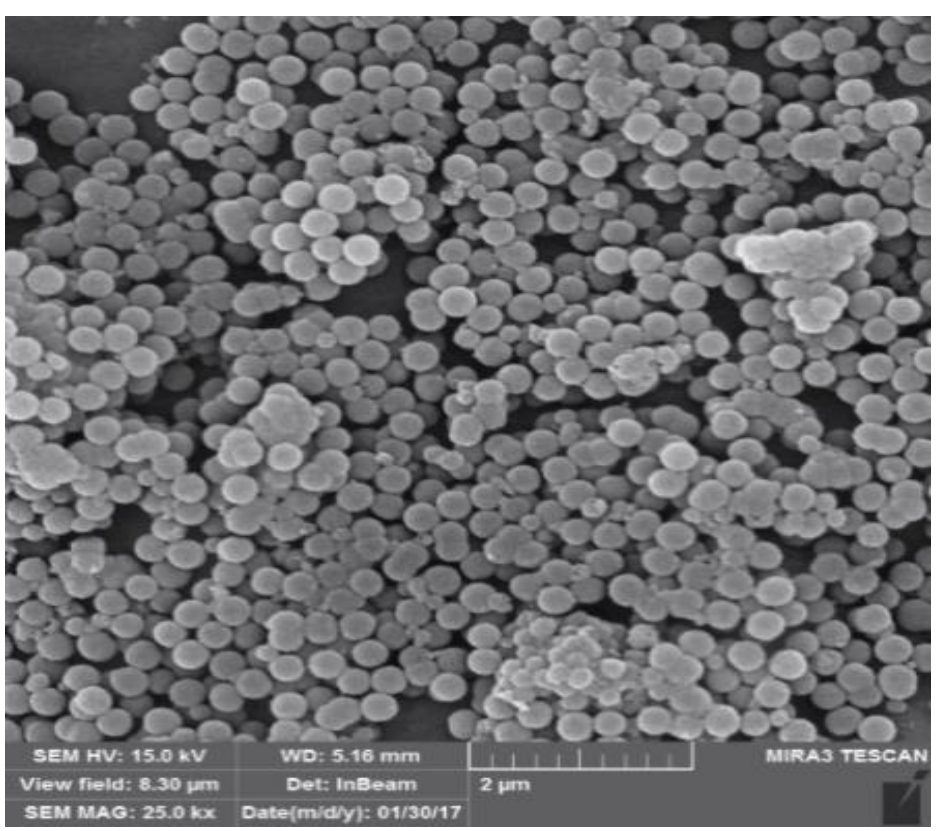

Figure 2. SEM image of HMSS.

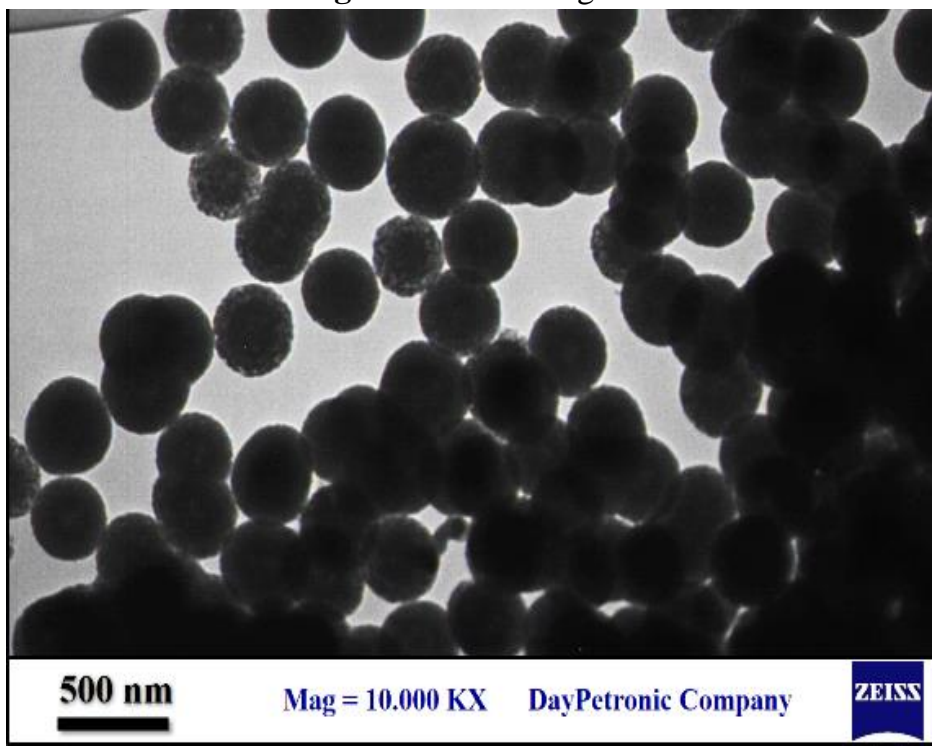

Figure 3. TEM image of HMSS. 


\subsection{TEM}

The TEM image of HMSS shows the uniform size distribution of particles (Figure 3). According to the TEM image, the core-shell structure can be distinguished, and the average size of HMSS is about $200 \mathrm{~nm}$. The thickness of the shell is estimated at $50 \mathrm{~nm}$.

\subsection{FT-IR.}

The FT-IR spectra are recorded at room temperature. It appeared consistent with HMSS (Fig. 4). Specifically, asymmetric and symmetric Si-O-Si stretching vibrations of HMSS is seen at $1084 \mathrm{~cm}-1$ and $800 \mathrm{~cm}-1$, respectively. The broadband located around $3442 \mathrm{~cm}-1$ belongs to the surface of silanols and probably adsorbed water molecules. The peak at 1634 $\mathrm{cm}^{-1}$ is assigned to the $\mathrm{H}-\mathrm{O}-\mathrm{H}$ bending vibrations of the free or adsorbed water molecules. After calcination, C-H stretch $(2855 \mathrm{~cm}-1$ and $2925 \mathrm{~cm}-1)$ peaks from the CTAB template disappears, indicating the loss of CTAB $[52,53]$.

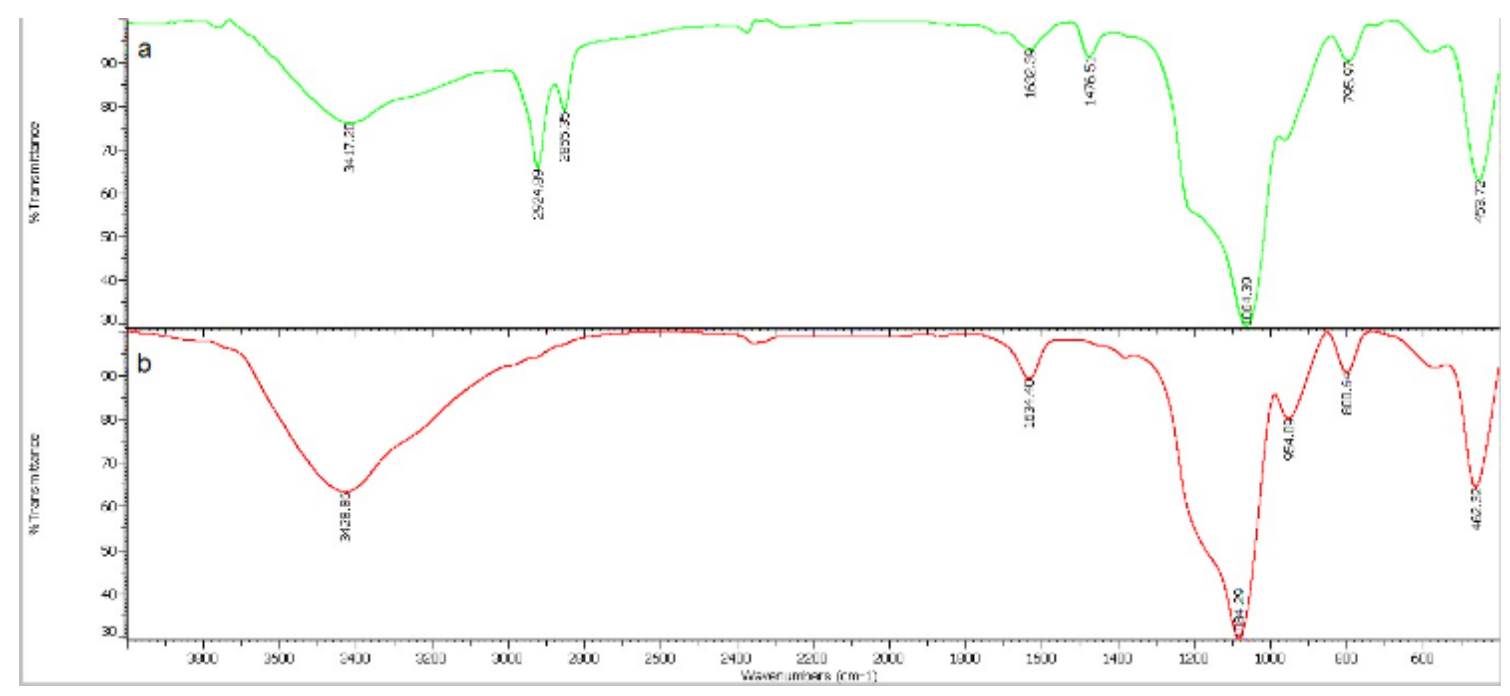

Figure 4. FT-IR spectra of HMSS, before calcination (a) after calcination (b).

\subsection{BET.}

The $\mathrm{N}_{2}$ adsorption and desorption measurements are applied to identify the physical characteristics of HMSS pores. The Brunauer-Emmett-Teller (BET) isotherm displays typical IV isotherm in the range of relative pressure $(\mathrm{p} / \mathrm{PO}=0.98)($ Fig. 5$)$. The total surface area, total pore volume, and average pore diameter are $835.82 \mathrm{~m} 2 / \mathrm{g}, 0.89 \mathrm{~cm} 3 / \mathrm{g}$, and $4.25 \mathrm{~nm}$, respectively. Barrett-Joyner-Halenda (BJH) shows average pore width with $2.74 \mathrm{~nm}$ and 3.24 $\mathrm{nm}$ for adsorption and desorption, respectively. The results verify that HMSS has uniform pores $[54,55]$.

\subsection{Application of the catalyst.}

Upon verification of the HMSS structure, it is utilized as a catalyst in one-pot multicomponent condensation of two sets of reactions. First, the three-component reactions of 1, 2, and 3 are conducted for the synthesis of 4 (Scheme 3). To optimize the conditions, reactions are carried out over various amounts of the catalyst, reactants, and solvents at different temperatures and reaction times. The results reveal no significant improvement by applying more than $10 \mathrm{mg}$ of the catalyst and show that water acts by far as the best solvent. 
To the reaction time and yield, the optimum reaction conditions need to use $10 \mathrm{mg}$ of the catalyst, $1 \mathrm{mmol}$ of each starting material (1-3), and $5 \mathrm{ml}$ water at $80{ }^{\circ} \mathrm{C}$ for $15 \mathrm{~min}$ (Table 1).

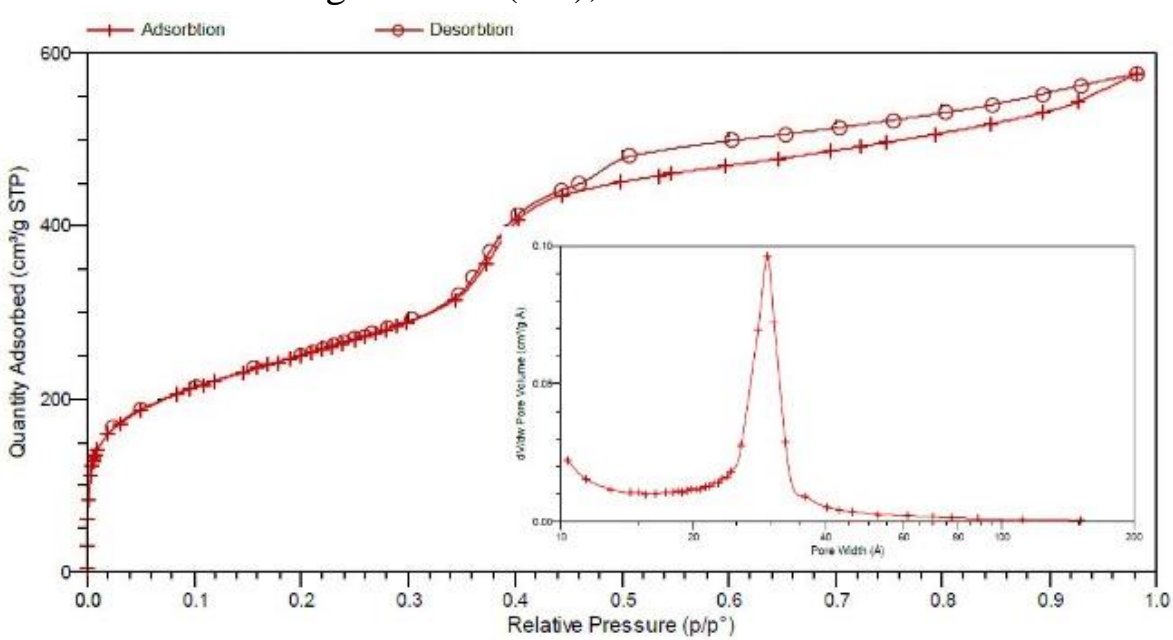

Figure 5. Nitrogen adsorption and desorption isotherms of HMSS.

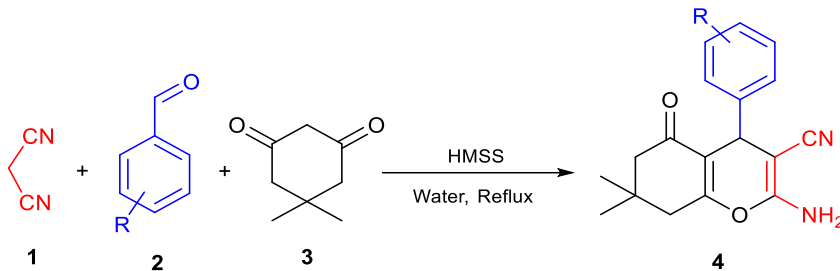<smiles>CC1(C)CC(=O)C2=C(C1)OC(N)=C(C#N)C2c1ccccc1</smiles>

$4 a, 91 \%, 228-230^{c}, 228-230^{\text {d, }}[39]$<smiles>Cc1ccc(C2C(C#N)=C(N)OC3=C2C(=O)CC(C)(C)C3)cc1</smiles>

4d, $87 \%, 214-215,210-213^{[41]}$<smiles>CC1(C)CC(=O)C2=C(C1)OC(N)=C(C#N)C2c1ccc(O)cc1</smiles>

$4 \mathrm{~g}, 90 \%, 214-215,204-205^{[41]}$<smiles>CC1(C)CC(=O)C2=C(C1)OC(N)=C(C#N)C2c1ccc([N+](=O)[O-])cc1</smiles>

$4 \mathrm{j}, 92 \%, 180-182,183-185^{[40]}$<smiles>CC1(C)CC(=O)C2=C(C1)OC(N)=C(C#N)C2c1ccccc1Cl</smiles>

4b, $83 \%, 201-202,200-202^{[40]}$<smiles>COc1ccc(C2C(C#N)=C(N)OC3=C2C(=O)CC(C)(C)C3)cc1</smiles>

$4 e, 93 \%, 195-196,197-199^{[42]}$<smiles>CC1(C)CC(=O)C2=C(C1)OC(N)=C(C#N)C2c1ccc(C#N)cc1</smiles>

$4 h, 92 \%, 225-226,226-227^{[40]}$<smiles>CN(C)c1ccc(C2C(C#N)=C(N)OC3=C2C(=O)CC(C)(C)C3)cc1</smiles>

4k, 95\%, 213-214, 213-215 ${ }^{[43]}$

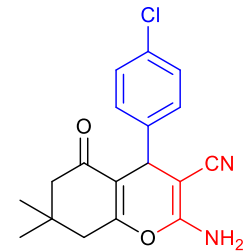

4c, $89 \%, 214-215,214-216^{[39}$<smiles>CC1(C)CC(=O)C2=C(C1)OC(N)=C(C#N)C2c1cccc(O)c1</smiles>

4f, $90 \%, 232-234,231-233^{[41]}$<smiles>CC1(C)CC(=O)C2=C(C1)OC(N)=C(C#N)C2c1cccc([N+](=O)[O-])c1</smiles>

4i, 91\%, 205-207, 204-206 [40]

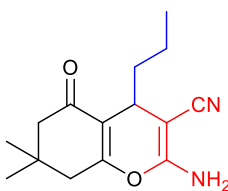

4I, $89 \%, 175-176,174-176[40$

Scheme 3. HMSS catalyzed synthesis of 4 through the one-pot three-component reaction of 1,2 , and 3 . $^{\mathrm{a}, \mathrm{b}}$ 
Reaction conditions: 1 (1 mmol), 2 (1 mmol), and 3 (1 mmol), over HMSS (10 mg) are refluxed in water for $15 \mathrm{~min}$. b Isolated yields Found melting points [55].d Reported melting points [55].

Secondly, one-pot three-component synthesis is carried out involving 1 (1 mmol), 2 (1 $\mathrm{mmol})$, and $5(1 \mathrm{mmol})$, giving 6 under the solvent-free condition. The percentage yields of 6 ranges from good to moderate (Scheme 4).<smiles>[R]c1ccc(C2C(C#N)=C(N)OC(C)=C2C(=O)OCC)cc1</smiles><smiles>CCOC(=O)C1=C(C)OC(N)=C(C#N)C1c1ccccc1</smiles><smiles>CCOC(=O)C1=C(C)OC(N)=C(C#N)C1c1ccc(Cl)cc1</smiles><smiles>CCOC(=O)C1=C(C)OC(N)=C(C#N)C1c1ccc(C)cc1</smiles>

6a, $91 \%, 194-195^{\mathrm{C}}, 195-196^{\mathrm{d},[42]}$

6b, $90 \%, 170-171,172-174[42]$

6c, $91 \%, 174-176,177-179^{[42]}$<smiles>CCOC(=O)C1=C(C)OC(N)=C(C#N)C1c1ccc(OC)cc1</smiles><smiles>CCOC(=O)C1=C(C)OC(N)=C(C#N)C1c1cccc(O)c1</smiles><smiles>CCOC(=O)C1=C(C)OC(N)=C(C#N)C1c1cccc([N+](=O)[O-])c1</smiles>

6d, $89 \%, 139-141,142-144^{[42]}$

6e, $87 \%, 162-164,164-165^{[42]}$

$6 f, 88 \%, \quad 183-185,182-183^{[42]}$<smiles>CCOC(=O)C1=C(C)OC(N)=C(C#N)C1c1ccc([N+](=O)[O-])cc1</smiles><smiles>CCOC(=O)C1=C(C)OC(N)=C(C#N)C1c1ccc(C#N)cc1</smiles>

$6 g, 93 \%, 182-184,180-183^{[42]}$

6h, $94 \%, 171-173,170-172$

Scheme 4. HMSS catalyzed synthesis of 6 through the one-pot three-component reaction of 1,2 , and 5 . $^{\mathrm{a}, \mathrm{b}}$

a Reaction conditions: 1 (1 mmol), 2 ( $1 \mathrm{mmol})$, and 5 (1 mmol), over HMSS (10 mg) are stirred at $60{ }^{\circ} \mathrm{C}$ for $10 \mathrm{~min}$.

b Isolated yields.c Found melting points [55].d Reported melting points [55].

Table 1. Optimization of reaction conditions

\begin{tabular}{c|c|c|c|c|c|c} 
Entry & Catalyst & Solvent & Amount of catalyst $(\mathrm{mg})$ & Temp. $\left({ }^{\circ} \mathrm{C}\right)$ & Time $(\mathrm{min})$ & Yield $(\%)$ \\
\hline $\mathbf{1}$ & - & $\mathrm{H}_{2} \mathrm{O}$ & - & r.t. & 180 & - \\
\hline $\mathbf{2}$ & - & $\mathrm{H}_{2} \mathrm{O}$ & - & 90 & 120 & 22 \\
\hline $\mathbf{3}$ & - & - & - & 60 & 120 & 25 \\
\hline $\mathbf{4}$ & HMSS & - & 5 & 60 & 10 & 87 \\
\hline $\mathbf{5}$ & HMSS & - & 10 & 60 & 10 & 89 \\
\hline $\mathbf{6}$ & HMSS & - & $\mathbf{1 5}$ & $\mathbf{6 0}$ & $\mathbf{1 0}$ & $\mathbf{9 4}$ \\
\hline $\mathbf{7}$ & HMSS & - & 20 & 60 & 10 & 94 \\
\hline $\mathbf{8}$ & HMSS & - & 25 & 60 & 10 & 90
\end{tabular}




\begin{tabular}{c|c|c|c|c|c|c} 
Entry & Catalyst & Solvent & Amount of catalyst $(\mathrm{mg})$ & Temp. $\left({ }^{\circ} \mathrm{C}\right)$ & Time (min) & Yield $(\%)$ \\
\hline $\mathbf{9}$ & HMSS & MeOH & 15 & 60 & 10 & 90 \\
\hline $\mathbf{1 0}$ & HMSS & EtOH & 15 & 60 & 10 & 70 \\
\hline $\mathbf{1 1}$ & HMSS & Toluene & 15 & 105 & 15 & 18 \\
\hline $\mathbf{1 2}$ & HMSS & THF & 15 & 60 & 20 & 15 \\
\hline $\mathbf{1 3}$ & HMSS & $\mathrm{H}_{2} \mathrm{O}$ & 15 & 60 & 15 & 91
\end{tabular}

We suggest a possible mechanism for catalytic synthesis of 4 (Scheme 5). The catalyst renders the aldehyde more electrophilic hence, facilitating the nucleophilic attack of 1 led to intermediate I. After condensation, the activated 1 is prone to undergo Micheal addition to give the intermediate II. Then, deprotonation, ring closure via O-attack, and proton abstraction occur subsequently followed by proton transfer to afford the final product III.

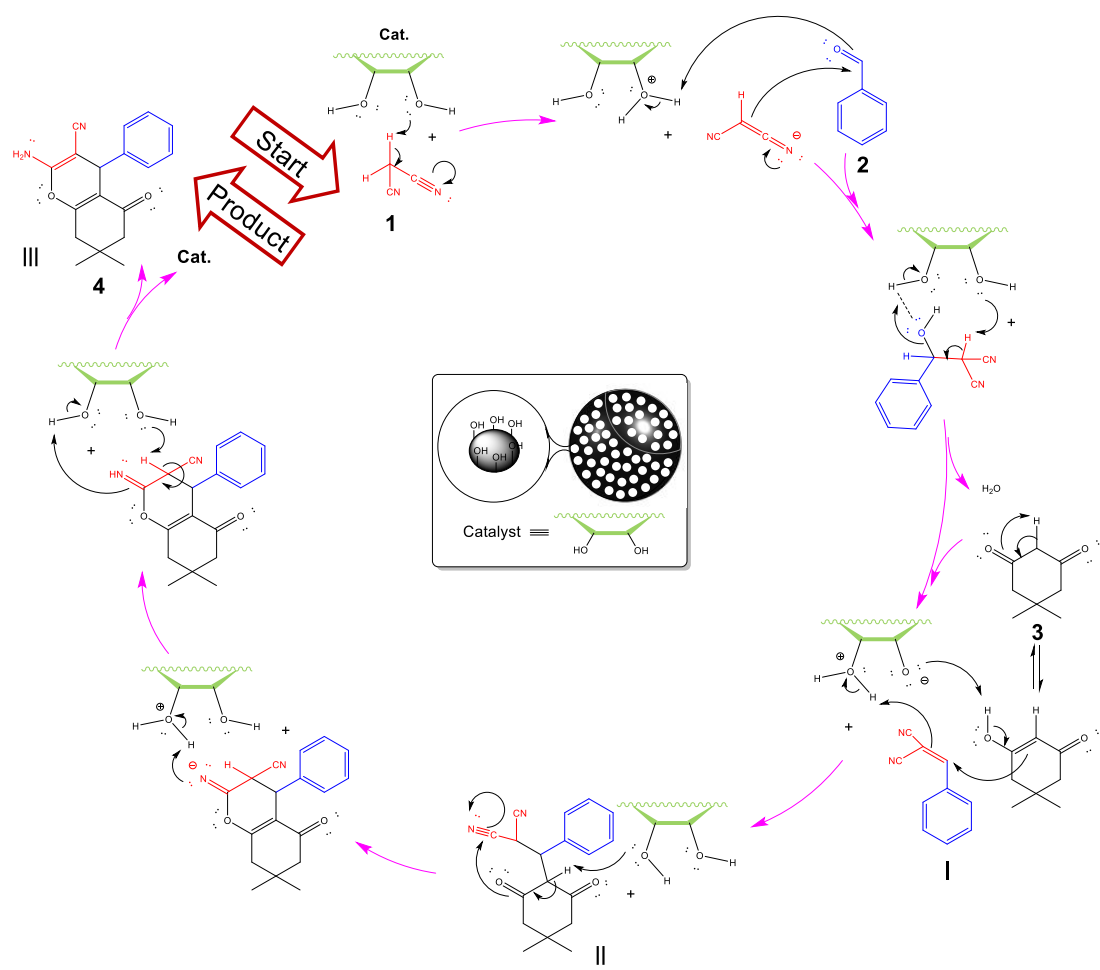

Scheme 5. The suggested reaction mechanism for the one-pot three-component reaction of 1, 2, and 3 via HMSS.

Our catalyst performance in the synthesis of 4 and 6 are compared and contrasted to those reported (Table 2). HMSS appears as the catalyst of choice for its high catalytic reactivity in terms of economic factors, especially using water instead of organic solvents and also solvent-free conditions, high yields, mild reaction conditions, and short reaction time.

Table 2. Comparison of HMSS with other reported catalysts used in the synthesis of 2-amino-3-cyano-4H-pyran derivatives.

\begin{tabular}{c|c|c|c|c|c} 
Product & Entry & Cat./Condition & $\begin{array}{c}\text { Time } \\
(\mathbf{M i n} .)\end{array}$ & $\begin{array}{c}\text { Yield } \\
(\boldsymbol{\%})\end{array}$ & Ref. \\
\hline \multirow{4}{*}{4} & 1 & $\mathrm{SiO}_{2} \mathrm{NPs}, \mathrm{EtOH}, \mathrm{rt}$ & 20 & 98 & {$[34]$} \\
\cline { 2 - 6 } & 2 & {$[\mathrm{ch}][\mathrm{OH}]^{\mathrm{a}}, \mathrm{H}_{2} \mathrm{O}, 80{ }^{\circ} \mathrm{C}$} & 120 & 96 & {$[35]$} \\
\cline { 2 - 6 } & 3 & $\mathrm{CsF}, \mathrm{EtOH}, \mathrm{rt}$ & 5 & 95 & {$[37]$} \\
\cline { 2 - 6 } & 4 & $\mathrm{Urea}, \mathrm{EtOH} / \mathrm{H}_{2} \mathrm{O}, \mathrm{rt}$ & 6 & 91 & {$[40]$} \\
\hline \multirow{4}{*}{6} & 5 & $\begin{array}{c}\mathrm{HMSS} \\
\mathrm{H}_{2} \mathrm{O}, \mathrm{Reflux}\end{array}$ & 15 & 95 & $\begin{array}{c}\text { This } \\
\text { work }\end{array}$ \\
\cline { 2 - 6 } & 6 & $\mathrm{NH}_{3}, \mathrm{EtOH}, \mathrm{rt}$ & 4 & 98 & {$[44]$} \\
\cline { 2 - 6 } & 7 & $\mathrm{NH}_{4} \mathrm{OH}, \mathrm{IR}, \mathrm{rt}$ & 10 & 98 & {$[45]$} \\
\hline & 9 & $\begin{array}{c}\mathrm{HMSS} \\
\text { Solvent Free, } 60{ }^{\circ} \mathrm{C}\end{array}$ & 10 & 94 & $\begin{array}{c}\text { This } \\
\text { work }\end{array}$
\end{tabular}

a Choline hydroxide (ionic liquid) 
Recyclability of HMSS is probed under optimal conditions. The catalyst is recycled five times, and its efficiency is changed from $95 \%$ to $80 \%$ for 4 and 6 (Figure 6). Specifically, the catalyst is easily removed from the reaction mixture via centrifuge, then dried at $80{ }^{\circ} \mathrm{C}$ to be prepared for further reactions. The recovered catalyst could be reused without any obvious alteration in its structure and decrement of the yields and used five times in the reactions to synthesize 4 and 6 (Figure 6).

The comparison of the FT-IR spectra to that of the fresh and recovered catalyst after five runs shows no obvious change in the structure and demonstrated high stability of the catalyst (Figure 7).

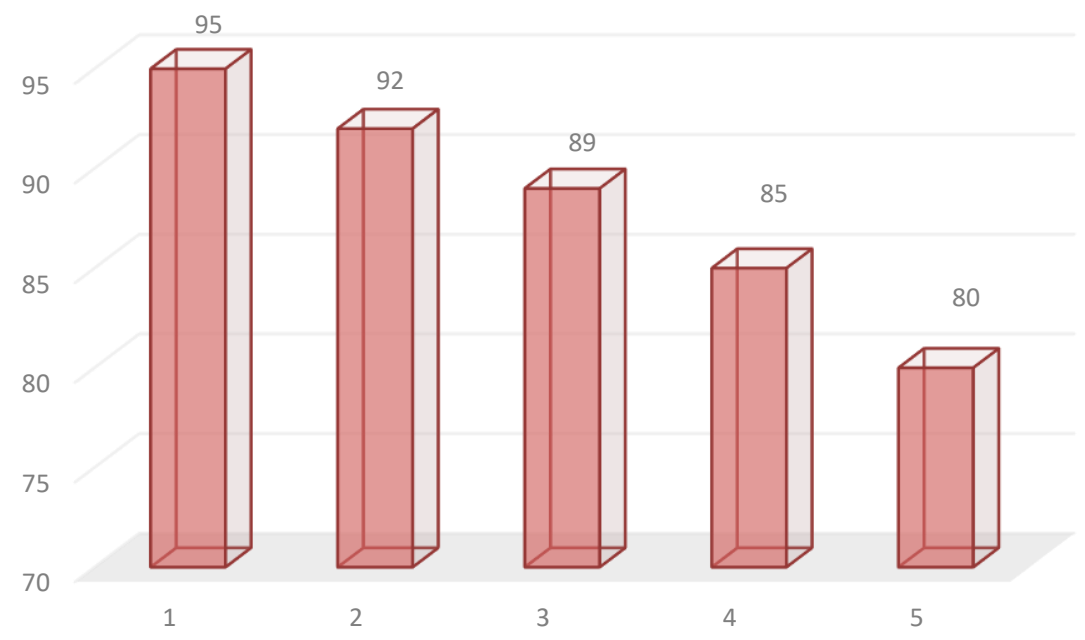

Figure 6. Recyclability of HMSS in the reaction to synthesize 4 and 6.

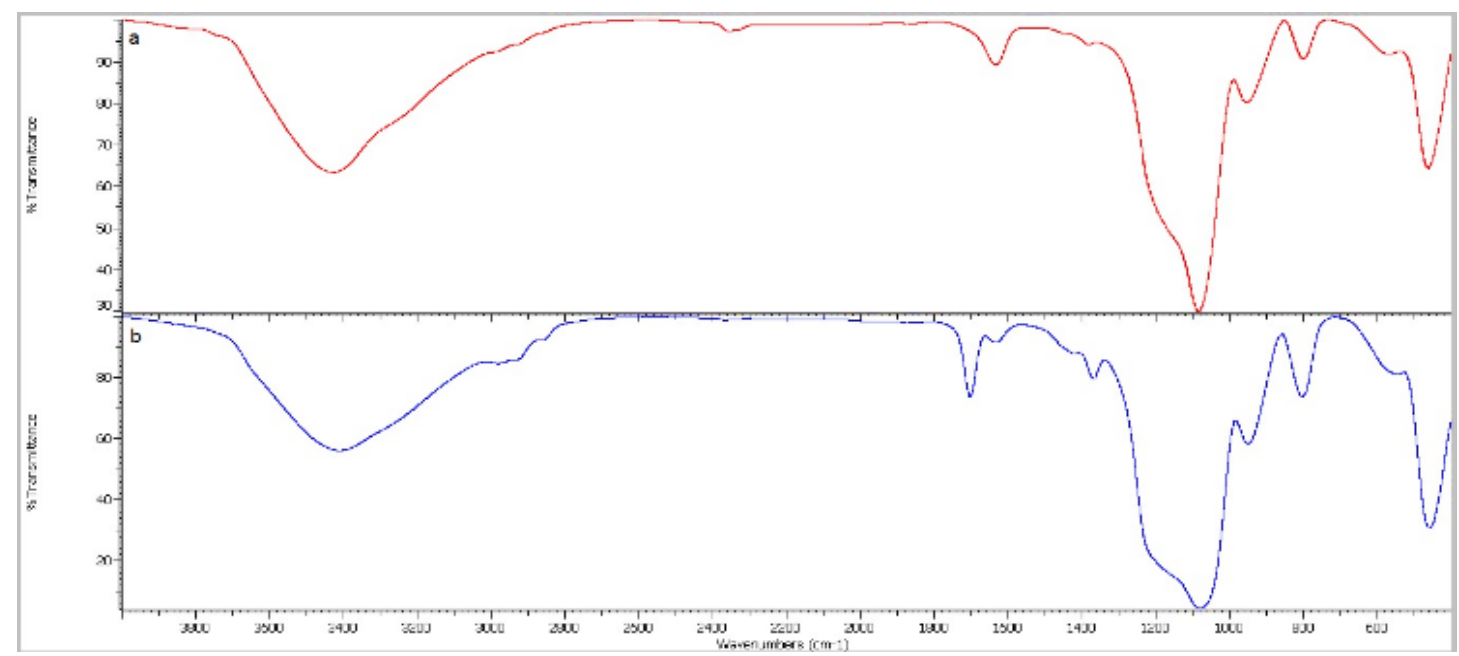

Figure 7. FT-IR spectra of fresh (a) and reused (b).

\section{Conclusions}

An efficient method was reached for the synthesis of 2-amino-3-cyano-4H-pyran derivatives through one-pot multicomponent reactions over the HMSS catalyst under mild condition. One of the major advantages of this approach was the role of water as green and ecofriendly solvent, encountered high yields, short reaction time, catalyst recyclability, high surface to volume ratio without any further functionalization of catalyst, and facile isolation of the products, low cost and atom, pot and step economy. 


\section{Funding}

There is no financial support.

\section{Acknowledgments}

We acknowledge Tarbiat Modares University for partial support of this work.

\section{Conflicts of Interest}

The authors declare no conflict of interest.

\section{References}

1. Caruso, F.; Caruso, R.A.; Mohwald, H. Nanoengineering of inorganic and hybrid hollow spheres by colloidal templating. Science 1998, 282, 1111-4, https://doi.org/10.1126/science.282.5391.1111.

2. Slowing, I.I.; Trewyn, B.G.; Giri, S.; Lin, V.Y. Mesoporous silica nanoparticles for drug delivery and biosensing applications. Adv. Funct. Mater 2007, 17, 1225-1236, https://doi.org/10.1002/adfm.200601191.

3. Slowing, I.I.; Vivero-Escoto, J.L.; Wu, C.W.; Lin, V.S.Y. Mesoporous silica nanoparticles as controlled release drug delivery and gene transfection carriers. Adv. Drug Deliv. Rev 2008, 60, 1278-1288, https://doi.org/10.1016/j.addr.2008.03.012.

4. Chen, J.; Xue, Z.; Feng, S.; Tu, B.; Zhao, D. Synthesis of mesoporous silica hollow nanospheres with multiple gold cores and catalytic activity. $J$ Colloid Interface Sci 2014, 429, 62-7, https://doi.org/10.1016/j.jcis.2014.05.005.

5. Chen, Y.; Chen, H.; Shi, J. In vivo bio-safety evaluations and diagnostic/therapeutic applications of chemically designed mesoporous silica nanoparticles. Adv. Mater 2013, 25, 3144-3176, https://doi.org/10.1002/adma.201205292.

6. Du, L.; Liao, S.; Khatib, H.A.; Stoddart, J.F.; Zink, J.I. Controlled-access hollow mechanized silica nanocontainers. J Am Chem Soc 2009, 131, 15136-42, https://doi.org/10.1021/ja904982j.

7. Park, J.C.; Bang, J.U.; Lee, J.; Ko, C.H.; Song, H. Ni@ SiO 2 yolk-shell nanoreactor catalysts: High temperature stability and recyclability. J. Mater. Chem 2010, 20, 1239-1246, https://doi.org/10.1039/B918446E.

8. Yamada, Y.; Mizutani, M.; Nakamura, T.; Yano, K. Mesoporous microcapsules with decorated inner surface: fabrication and photocatalytic activity. Chem. Mater 2010, 22, 1695-1703, https://doi.org/10.1021/cm9031072.

9. Hao, N.; Jayawardana, K.W.; Chen, X.; Yan, M. One-step synthesis of amine-functionalized hollow mesoporous silica nanoparticles as efficient antibacterial and anticancer materials. Acs Appl Mater Inter 2015, 7, 1040-1045, https://doi.org/10.1021/am508219g.

10. Zhou, J.; Hua, Z.; Wu, W.; Liu, Z.; Zhu, Y.; Chen, Y.; Shi, J. Hollow mesoporous zeolite microspheres: Hierarchical macro-/meso-/microporous structure and exceptionally enhanced adsorption properties. Dalton Trans 2011, 40, 12667-12669, https://doi.org/10.1039/C1DT11684C.

11. Fowler, C.E.; Khushalani, D.; Mann, S. Facile synthesis of hollow silica microspheres. J. Mater. Chem 2001, 11, 1968-1971, https://doi.org/10.1039/B102675P.

12. Lillis, B.; Jungk, C.; Iacopino, D.; Whelton, A.; Hurley, E.; Sheehan, M.M.; Splinter, A.; Quinn, A.; Redmond, G.; Lane, W.A.; Mathewson, A.; Berney, H. Microporous silicon and biosensor development: structural analysis, electrical characterisation and biocapacity evaluation. Biosens Bioelectron 2005, 21, 28292, https://doi.org/10.1016/j.bios.2004.09.031.

13. Song, J.C.; Xue, F.F.; Lu, Z.Y.; Sun, Z.Y. Controllable synthesis of hollow mesoporous silica particles by a facile one-pot sol-gel method. Chem Comm 2015, 51, 10517-10520, https://doi.org/10.1039/C5CC03025K.

14. Li, M.; Li, X.; Qi, X.; Luo, F.; He, G. Shape-controlled synthesis of magnetic iron oxide@ SiO2-Au@ C particles with core-shell nanostructures. Langmuir 2015, 31, 5190-5197, https://doi.org/10.1021/acs.langmuir.5b00800.

15. Martínez-Carmona, M.; Gun'ko, Y.K.; Vallet-Regí, M. Mesoporous silica materials as drug delivery:“The Nightmare" of bacterial infection. Pharmaceutics 2018, 10, 279, https://doi.org/10.3390/pharmaceutics10040279.

16. Narayan, R.; Nayak, U.Y.; Raichur, A.M.; Garg, S. Mesoporous Silica Nanoparticles: A Comprehensive Review on Synthesis and Recent Advances. Pharmaceutics 2018, 10, 118, https://doi.org/10.3390/pharmaceutics10030118.

17. Pratap Rao, D. A review on versatile applications of novel Schiff bases and their metal complexes. Lett. Appl. NanoBioScience 2019, 8, 675 -681, https://doi.org/10.33263/LIANBS84.675681. 
18. Lou, X.W.; Archer, L.A.; Yang, Z. Hollow micro-/nanostructures: Synthesis and applications. Adv. Mater 2008, 20, 3987-4019, https://doi.org/10.1002/adma.200800854.

19. Li, H.; Bian, Z.; Zhu, J.; Huo, Y.; Li, H.; Lu, Y. Mesoporous Au/TiO2 nanocomposites with enhanced photocatalytic activity. J Am Chem Soc 2007, 129, 4538-9, https://doi.org/10.1021/ja069113u.

20. Wang, T.; Ma, W.; Shangguan, J.; Jiang, W.; Zhong, Q. Controllable synthesis of hollow mesoporous silica spheres and application as support of nano-gold. J. Solid State Chem 2014, 215, 67-73, https://doi.org/10.1016/j.jssc.2014.03.003.

21. Li, J.; Liu, J.; Wang, D.; Guo, R.; Li, X.; Qi, W. Interfacially controlled synthesis of hollow mesoporous silica spheres with radially oriented pore structures. Langmuir 2010, 26, 12267-72, https://doi.org/10.1021/la101225j.

22. Wu, H.; Tang, B.; Wu, P. Novel hollow mesoporous silica spheres/polymer hybrid membrane for ultrafiltration. J. Phys. Chem. C 2012, 116, 2246-2252, https://doi.org/10.1021/jp2073045.

23. He, X.; Luan, S.; Wang, L.; Wang, R.; Du, P.; Xu, Y.; Yang, H.; Wang, Y.; Huang, K.; Lei, M. Facile loading mesoporous $\mathrm{Co} 3 \mathrm{O} 4$ on nitrogen doped carbon matrix as an enhanced oxygen electrode catalyst. Materials Lett 2019, 244, 78-82, https://doi.org/10.1016/j.matlet.2019.01.144.

24. Oh, C.; Lee, Y.G.; Choi, T.S.; Jon, C.U.; Oh, S.G. Facile synthesis of PEG-silica hybrid particles using onestep sol-gel reaction in aqueous solution. Colloid Surface A 2009, 349, 145-150, https://doi.org/10.1016/j.colsurfa.2009.08.008.

25. Zhao, M.; Zheng, L.; Bai, X.; Li, N.; Yu, L. Fabrication of silica nanoparticles and hollow spheres using ionic liquid microemulsion droplets as templates. Colloid Surface A 2009, 346, 229-236, https://doi.org/10.1016/j.colsurfa.2009.06.021.

26. Melvin, A.; Vijay, R.; Chaudhari, V.R.; Gupta, B.; Prakash, R.; Haram, S.; Baskar, G.; Khushalani, D. A facile methodology for the design of functionalized hollow silica spheres. J Colloid Interface Sci 2010, 346, 265-9, https://doi.org/10.1016/j.jcis.2010.02.026.

27. Xie, F.; Zhang, L.; Su, D.; Jaroniec, M.; Qiao, S.Z. Na2Ti3O7@ N-Doped Carbon Hollow Spheres for Sodium-Ion Batteries with Excellent Rate Performance. Adv Mater 2017, 29, https://doi.org/10.1002/adma.201700989.

28. Lin, Y.S.; Wu, S.H.; Tseng, C.T.; Hung, Y.; Chang, C.; Mou, C.Y. Synthesis of hollow silica nanospheres with a microemulsion as the template. Chem Comm 2009, 3542-3544, https://doi.org/10.1039/B902681A.

29. Nasresfahani, Z.; Kassaee, M.Z.; Nejati-Shendi, M.; Eidi, E.; Taheri, Q. Mesoporous silica nanoparticles (MSNs) as an efficient and reusable nano-catalyst for synthesis of $\beta$-amino ketones through one-pot threecomponent Mannich reactions. RSC Adv 2016, 6, 32183-32188, https://doi.org/10.1039/C6RA02454H.

30. Rajesh, U.C.; Kholiya, R.; Pavan, V.S.; Rawat, D.S. Catalyst-free, ethylene glycol promoted one-pot three component synthesis of 3-amino alkylated indoles via Mannich-type reaction. Tetrahedron Lett 2014, 55, 2977-2981, https://doi.org/10.1016/j.tetlet.2014.03.112.

31. Kitanosono, T.; Masuda, K.; Xu, P.; Kobayashi, S. Catalytic Organic Reactions in Water toward Sustainable Society. Chem Rev 2018, 118, 679-746, https://doi.org/10.1021/acs.chemrev.7b00417.

32. Yang, X.; Liao, S.; Zeng, J.; Liang, Z. A mesoporous hollow silica sphere (MHSS): Synthesis through a facile emulsion approach and application of support for high performance Pd/MHSS catalyst for phenol hydrogenation. Appl. Surf. Sci 2011, 257, 4472-4477, https://doi.org/10.1016/j.apsusc.2010.12.096.

33. Li, Y.; Bastakoti, B.P.; Abe, H.; Liu, Z.; Minett, A.; AL Othman, Z.A.; Yamauchi, Y. A dual soft-template synthesis of hollow mesoporous silica spheres decorated with Pt nanoparticles as a CO oxidation catalyst. RSC Adv 2015, 5, 97928-97933, https://doi.org/10.1039/C5RA17340J.

34. Slowing, I.I.; Vivero-Escoto, J.L.; Trewyn, B.G.; Lin, V.S.Y. Mesoporous silica nanoparticles: structural design and applications. J. Mater. Chem 2010, 20, 7924-7937, https://doi.org/10.1039/C0JM00554A.

35. Shen, Y.; Jiang, P.; Zhang, J.; Bian, G.; Zhang, P.; Dong, Y.; Zhang, W. Highly dispersed molybdenum incorporated hollow mesoporous silica spheres as an efficient catalyst on epoxidation of olefins. Mol Catal 2017, 433, 212-223, https://doi.org/10.1016/j.mcat.2016.12.011.

36. Lopez, T.; Ortiz, E.; Alvarez, M.; Navarrete, J.; Odriozola, J.A.; Martinez-Ortega, F.; Paez-Mozo, E.A.; Escobar, P.; Espinoza, K.A.; Rivero, I.A. Study of the stabilization of zinc phthalocyanine in sol-gel TiO2 for photodynamic therapy applications. Nanomedicine 2010, 6, 777-85, https://doi.org/10.1016/j.nano.2010.04.007.

37. Zindani, D.; Kumar, K. Graphene-based polymeric nano-composites: An introspection into functionalization, processing techniques and biomedical applications. Biointerface Res. Appl. Chem 2019, 9, 3926-3933, https://doi.org/10.33263/briac93.926933.

38. Li, Y.; Song, F.; Cheng, L.; Qian, J.; Chen, Q. Functionalized Large-Pore Mesoporous Silica Microparticles for Gefitinib and Doxorubicin Codelivery. Materials (Basel) 2019, 12, https://doi.org/10.3390/ma12050766.

39. Liu, H.J.; Xu, P. Smart Mesoporous Silica Nanoparticles for Protein Delivery. Nanomaterials (Basel) 2019, 9, https://doi.org/10.3390/nano9040511.

40. Rostamizadeh, S.; Nojavan, M.; Aryan, R.; Azad, M. Dual Acidic Ionic Liquid Immobilized on $\alpha$-Fe 2 O $3-$ MCM-41 Magnetic Mesoporous Materials as the Hybrid Acidic Nanocatalyst for the Synthesis of Pyrimido [4, 5-d] pyrimidine Derivatives. Catal Lett 2014, 144, 1772-1783, https://doi.org/10.1007/s10562-014$1330-5$. 
41. Girija, A.R.; Balasubramanian, S. Theragnostic potentials of core/shell mesoporous silica nanostructures. Nanotheranostics 2019, 3, https://doi.org/10.7150/ntno.27877.

42. Banerjee, S.; Horn, A.; Khatri, H.; Sereda, G. A green one-pot multicomponent synthesis of 4H-pyrans and polysubstituted aniline derivatives of biological, pharmacological, and optical applications using silica nanoparticles as reusable catalyst. Tetrahedron Lett 2011, 52, 1878-1881, https://doi.org/10.1016/j.tetlet.2011.02.031.

43. Hu, H.; Qiu, F.; Ying, A.; Yang, J.; Meng, H. An environmentally benign protocol for aqueous synthesis of tetrahydrobenzo[b]pyrans catalyzed by cost-effective ionic liquid. Int J Mol Sci 2014, 15, 6897-909, https://doi.org/10.3390/ijms15046897.

44. Gupta, A.; Jamatia, R.; Pal, A.K. Ferrite-supported glutathione: an efficient, green nano-organocatalyst for the synthesis of pyran derivatives. New J Chem 2015, 39, 5636-5642, https://doi.org/10.1039/C5NJ00657K.

45. Wagh, Y.B.; Tayade, Y.A.; Padvi, S.A.; Patil, B.S.; Patil, N.B.; Dalal, D.S. A cesium fluoride promoted efficient and rapid multicomponent synthesis of functionalized 2-amino-3-cyano-4H-pyran and spirooxindole derivatives. Chinese Chem Lett 2015, 26, 1273-1277, https://doi.org/10.1016/j.cclet.2015.06.014.

46. Becit, B.; Duchstein, P.; Zahn, D. Molecular mechanisms of mesoporous silica formation from colloid solution: Ripening-reactions arrest hollow network structures. PLoS One 2019, 14, e0212731, https://doi.org/10.1371/journal.pone.0212731.

47. Chen, W.; Cheng, C.A.; Cosco, E.D.; Ramakrish nan, S.; Lingg, J.G.P.; Bruns, O.T.; Zink, J.I.; Sletten, E.M. Shortwave Infrared Imaging with J-Aggregates Stabilized in Hollow Mesoporous Silica Nanoparticles. J Am Chem Soc 2019, 141, 12475-12480, https://doi.org/10.1021/jacs.9b05195.

48. Keshavarz, S.; Naimi-Jamal, M.R.; Izadmanesh, Y.; Dekamin, M.G. Synthesis of ionic liquids with multifunctional tribological properties as excellent single-component package additives for turbine oils. $\mathrm{Lubr}$ Sci 2019, 31, 311-320, https://doi.org/10.1002/ls.1473.

49. Kazeminezhad, I.; Mosivand, S. Size Dependence of Electrooxidized Fe3O4 Nanoparticles on Surfactant Concentration. Acs Appl Mater Inter 2011, 74 338-341.

50. Banik, A.; Ansari, M.S.; Qureshi, M. Efficient Energy Harvesting in SnO2-Based Dye-Sensitized Solar Cells Utilizing Nano-Amassed Mesoporous Zinc Oxide Hollow Microspheres as Synergy Boosters. ACS omega 2018, 3, 14482-14493, https://doi.org/10.1021/acsomega.8b02520.

51. Flodström, K.; Teixeira, C.V.; Amenitsch, H.; Alfredsson, V.; Lindén, M. In situ synchrotron small-angle $\mathrm{X}$-ray scattering/X-ray diffraction study of the formation of SBA-15 mesoporous silica. Langmuir 2004, 20, 4885-4891, https://doi.org/10.1021/la049637c.

52. Putz, A.M.; Putz, M.V. Spectral inverse quantum (Spectral-IQ) method for modeling mesoporous systems: application on silica films by FTIR. Int J Mol Sci 2012, 13, 15925-41, https://doi.org/10.3390/ijms131215925.

53. Nandi, T.; Dash, D.; Ghai, R.; C, B.R.; Kannan, K.; Brahmachari, S.K.; Ramakrishnan, C.; Ramachandran, S. A novel complexity measure for comparative analysis of protein sequences from complete genomes. $J$ Biomol Struct Dyn 2003, 20, 657-68, https://doi.org/10.1080/07391102.2003.10506882.

54. Zhang, H.; Feng, L.; Liu, B.; Tong, C.; Lü, C. Conjugation of PPV functionalized mesoporous silica nanoparticles with graphene oxide for facile and sensitive fluorescence detection of TNT in water through FRET. Dyes Pigm 2013, 101, 122-129, https://doi.org/10.1016/j.dyepig.2013.09.040.

55. Schmidt, R.; Hansen, E.W.; Stöcker, M.; Akporiaye, D.; Ellestad, O.H. Pore size determination of MCM-51 mesoporous materials by means of 1H NMR spectroscopy, N2 adsorption, and HREM. A preliminary study. J. Am. Chem. Soc 1995, 117, 4049-4056, https://doi.org/10.1021/ja00119a021. 